\title{
Relationship between Leadership Commitment and Performance of Public Sector Universities of Punjab, Pakistan
}

\author{
HAJRA BIBI \\ Institute of Education and Research, University of the Punjab Lahore, Pakistan. \\ Email: hajrariaz@ fjwu.edu.pk \\ Tel: +923325735066 \\ MAHR MUHAMMAD SAEED AKHTAR \\ Institute of Education and Research, University of the Punjab, Lahore-Pakistan. \\ Email: mahrsaeed1@yahoo.com
}

\begin{abstract}
The current study aims to examine the relationship between leadership commitment and performance of the public sector universities of the province of Punjab, Pakistan. The Public sector universities are referred as Higher Education Organizations (HEOs) in this study. The study is quantitative and the data were collected by means of survey from the respondents. The study includes public sector general category universities of the Province (Punjab, Pakistan) which are located in the different areas of the province. There are twelve general public sector universities in the Province among those seven were included in the population which comprised of department heads, teaching faculty and students. The findings of the study revealed that there is a moderate positive relationship between leadership commitment and performance of HEOs. Three sub-factors of commitment have been included in the study in order to examine the role of leadership commitment. The findings of the study show that the continuance commitment influences HEOs performance. The highest correlation of continuance commitment has practical implications for HEOs performance. The leaders who have spent several years of their lives to serve institutions are more knowledgeable, skillful and experienced, therefore, they are in a better situation to manage the tasks. On the basis of the findings, it can be concluded that merely leadership is not sufficient for improvement of performance, but there is also a need of supportive and committed team in order to excel.
\end{abstract}

Keywords: Leadership Commitment, Public Sector Universities, Performance, Punjab, Pakistan.

\section{Introduction}

Leaders play a prime role in the progress and development of their respective institutions. They set directions and guide their individuals in right direction. In educational institutions principals, vice chancellors, deans, directors and heads of departments do the same to uplift the quality standards and flourish the culture of excellence. Higher educational institutions, particularly, striving for best to meet the national as well as international quality measures.

Educational services' quality has been defined in a vague way. Education can be considered as activities as well as processes which are aimed to transfer knowledge, shape specific traits and skills. To put it in another way, Education is also the sum of activities that are aimed to prepare a person to live in harmony with a society. It also helps an individuals' intellectual, moral as well as mental development. According to Mohsin and Kamal (2012) "the area of quality of education is related to the overall or general competitiveness of an institution of higher education in a variety of ranking lists, the level of its staff, the status of graduates, its material basis, quantitative indicators and qualitative achievements of students, the 
number of scientific projects, etc" (p. 64). One of the following three components are related to the generally understood definition of the quality of education. They further describe factors which are being included in services of university, "these factors are: the degree of fulfilment of assumed standard (measured in a quantitative or qualitative way), the degree of student's satisfaction from the service offered by the university (the market approach), the degree of fulfilment of assumed objectives, connected with the process of education (effectiveness in achieving these goals)" (p. 67). Moreover, it is also possible to assess the quality externally that is based on the objective data. Furthermore, there is also a subjective way to assess as well as interpret utility of individual in a society.

All the prescribed and exited quality assurance criteria ultimately determine the performance of institutions. As quality is a multi-faced concept, therefore, institutional performance also defined in different measure. Performance can be measured by using objective measures as well as it includes subjective measures. Subjective performance involves perception of stakeholders and their satisfaction with institutional performance. In service sector subjective performance measurement is being taken as quality assurance and also used for performance measurement. Performance does not only confined to quantitative measure rather in service sector it expands its spectrum to the satisfaction of stakeholders (Kapur, 2019). Performance of educational institutions mainly rely upon the leadership involvement and participation in improvement process. This study also examines relationship between leadership commitment and performance of public sector universities of Punjab, Pakistan. As stakeholders, perception of students and faculty members have been taken in order to gather information about their satisfaction with the services of their institutions.

According to Ulewicz (2017) “Quality of education can be evaluated through the lens of a lecturer's success, his or her knowledge, skills and competence, as well as the ability to create facilitating atmosphere between a lecturer and students" (p.95). Their perception and satisfaction has significant value in performance measurement, as their feedback set institutional image. Ulewicz (2017) also highlights the importance of these stakeholders in his words as "its management strategy includes actions aiming to fulfil the needs and requirements of students, employees, the management staff, as well as its graduates, and entrepreneurs. A process of monitoring the needs and expectations of students is being constantly performed, which constitutes an important element in creating a proper image of the University and ensuring competitive advantage" (p.95). He emphasis the worth of stakeholders' in his words as "internal and external stakeholders have a substantial impact on the effectiveness of the university's functioning" (p.99). Therefore, current study includes stakeholders to determine the performance of public sector universities. Furthermore, heads of departments, deans and directors were part of study as leaders of their respective institutions. They all are actively involved in day to day activities and ensure implementations of plans and policies. This study aims to identify:

(1) find out the relationship among leadership commitment and performance of public sector universities of the Punjab, Pakistan.

(2) determine the nature of the relationship among leadership commitment and performance of public sector universities of the Punjab, Pakistan.

(3) measure the strength of leadership commitment with performance of public sector universities.

On the basis of research objectives following are the research questions of the study:

(1) is there any relationship among leadership commitment and performance of public sector universities?

(2) what is the nature of relationship among leadership commitment and performance of the public sector universities?

(3) does strong leadership commitment result in good performance of public sector universities? 


\section{Literature Review}

Literature contains enrich content related to the leadership in which leadership has been incorporated with various hierarchical levels such as individuals, units as well as organizational levels therefore it is considered very important, moreover leaders are deputed many responsibilities in organizations (Yammarino, Dionne, Chun \&Dansereau, 2005; Mumford, Campion \&Morgeson, 2007). According to Leadership behaviors, leadership is definite as an influence relationship between leaders as well as followers who are desirous of concrete changes and outcomes that must reflect their shared purposes. Over time, as the researchers continue to explore that what are the important contributions to leadership's success and failure then various dimensions and of leadership behavior are being developed. In the past researches (Jackson, Meyer \& Wang, 2013) in the area of "leadership behavior" of directive, supportive and participative found relationship on commitment. Commitment is very important since it positively influences organizational effectiveness and wellbeing of employees. The concept of commitment has been defined as well as measured in various ways. Although the "existence of multiple dimensions or forms of commitment" have been acknowledged however, there has to be a core essence of commitment that distinguishes it from other constructs and characterizes its unique form (Meyer \&Herscovitch, 2001). They considered the implications of different mind-sets on behavior and also developed a mechanism through which three mind-sets such as affective, continuance and normative commitment are involved. They contended that "affective commitment" must be linked to a wide range of behaviors as compared to the other forms of commitment even when the focal behavior is clearly measured as well as specified. Focal behavior as well as target of interest must be specified in the objectives of research on commitment. Two "versions of a measure of "organization commitment" one that focuses on membership and the other that focuses on the attainment of "organizational goal" are considered in order to explain that how the focal behavior can be varied depending on the interest of the researchers. Various researches in the area of the organizational commitment literature have shown associated behavioral outcomes with commitment (Wright, 1997; Nasomboon, 2014).

In most of the studies, a relationship has been pointed out between leadership and institutional performance. Elenkov (2002) contends that an "effective leader" always focuses on that how institutions upgrade the performance and face the present and future challenges in order to achieve the "organizational objective". Whitener Brodt, Korsgaard\& Werner (1998) argues that leaders always play an important role in order to establish and develop a trust within institutional aspect. Dirks and Skarlicki (2004) contends that trust is a very important principle that is based on the relationships among individuals in a company and it helps to achieve institutional goal. Presently, there is a dearth of research studies that investigates the role of trust of person, group, leaders as well as institutions.

According to Spiegelhalter (2005) "institutional performance refers to the skill sets of any type of organization that is based on the high profit, innovation, quality, development, huge market share, good financial outcomes for gaining competitive advantages as compared to other organization" (p. 134). Further he shed light on the concept of institutional performance by stating that "institutional performance can also be explained as an organization getting more profit, good results, and market strategy as well as running in stress condition. Thus, it is a light of the improvement in productivity, revenue, growth, development and expansion of the organization" (p. 137).Pounder (1999) defines institutional performance as achievement of desired goals and successful implementation of educational plans and polices. So, his concept of institutional performance destined to practical aspect of the goals and objectives. According to Shin (2010) institutional performance are supposed to be fantastically renewed with a positive and a beneficial "institutional society which in turn builds the individual performance less absenteeism and less firing worker turnover" (p.189). In another study Armstrong and Baron (1998) argue that institutional performance is very important and an effective approach that helps to accomplish institutional goals. Alexander (2000) argued that a leader who is endowed with various qualities has the power to influence the followers as well as supporters in order to achieve a common goal. 
In any organization, the role of the leader depends and linked with the performance of an organization. Choudhary, Akhtar and Zaheer (2013) argued that leadership is a very vital element of management as well as development source of human resource; furthermore it helps in gaining sustained competitive advantage in order to improve institutional performance. Kakavogianni (2009) contends that leadership helps the employees to get maximum performance and also to get the current objectives of the institution. Leadership has great importance since it influences the condition of the organization. Any type of organization needs good leaders who can encourage their follower by increasing employee engagement in order to boost the performance of business. There are various potential variables which are associated with leadership behavior and they play a significant role. Kiue (2010) stated that the behaviors of top-level leadership play a vital role in the organization. Leaders are very important elements in the success of any type of organization. Highly competent leaders are the key to the development of an environment that helps to achieve organizational goals. As effective leaders have been shown to be predicative of attitudes and performance in organizations, the question was raised regarding whether other leadership behaviors would also be predictive the same way. It has been suggest in the studies about management literature that top management commitment may have a great impact on organizational practices (Dubey, Gunasekaran, Childe, Papadopoulos, Hazen \&Roubaud, 2018). According to Meyer and Herscovitch (2001) there are various forms of commitment in the workplace and they have the potential to influence organizational practices. Great leaders are need by all the organizations since they positively influence their co-workers and help to achieve organizational goals. Commitment of leadership is a key to the outcome of organizations. Thus, those leaders who have proved to be committed play a vital role in order to develop a suitable environment that renders organizational effectiveness (Keller, 2006).

\section{Materials and Methods}

This study is quantitative in nature and is based on positivist research paradigm. Quantitative research allows researchers to collect data in numerical form, test the associations between the variables and generalize the results.

\section{Study Design}
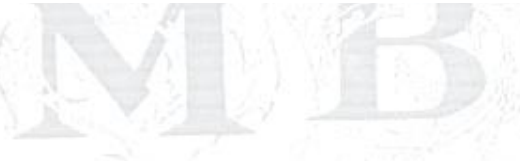

The study was "quantitative in nature" and data were collected by means of survey. Quantitative approach allows the researchers to collect data from large population and generalize the obtained results. Close ended questionnaires were used both questionnaires were adapted and used after confirming reliability and validity to ensure the usability of the tools in local context. Current study included seven public sector universities which are located in different areas of Pakistan, therefore, quantitative approach and survey design was appropriate for the conduction of study. Pakistan has five major administrative units; Punjab, Sindh, Blochistan, Khyber PakhtunKhawa and GilgitBalistan. These units referred as province and provincial government is responsible to manage the province with the cooperation of federal government. However, Higher Education Organizations are regulated by Higher Education Commission (HEC) and this regulated authority is governed by state.

\section{Population and Sample}

Universities included in the study represent the general category universities and population consisted of Heads of departments, faculty members and students from the faculty of "social sciences". Total number of participants was 1980, among those 47 were "heads of departments, 475 faculty members and 1458 were of students". These participants were from the public sector universities of the Punjab Pakistan.

\section{Analysis}

Following are the results of the study presented in the form of tables and figures. Table 1 presents the reliability analysis. 
Table: No 1

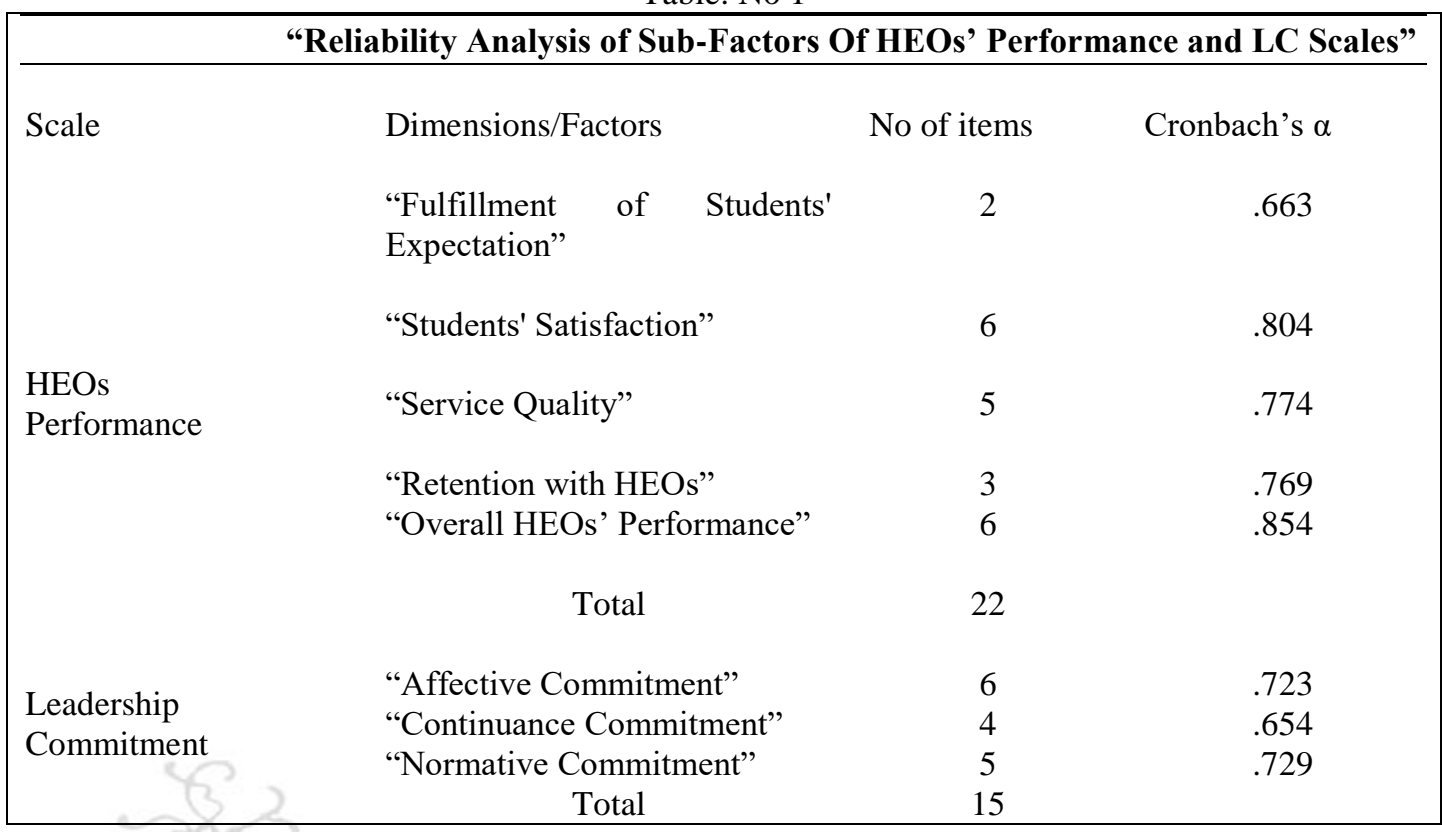

Table 1 illustrates "the pilot study before the applications of the questionnaire on the actual sample the Higher Education Organizations' Performance (HEOs') has the Cronbach alpha of .915 indicating high reliability. However this indicates the reliability of sub scales applied in actual study also indicates the validity of the scales in the Pakistani context research in which some variation in the reliability can be expected due to two main reasons: Respondents biasness factor and another may be due to the readability of the questionnaire items and their understanding". The reliability of sub-scales of leadership commitment also seems acceptable and ensure its usability in the local context. Table 2 contains level of performance in higher educational organizations.

Table: No 2

\begin{tabular}{|c|c|c|c|c|}
\hline \multicolumn{5}{|c|}{ "Level of HEOs' Performance and LC in Terms of Mean \& Median" } \\
\hline Scale & Dimensions/Factors & Mean & $S D$ & Median \\
\hline \multirow{7}{*}{ HEOs Performance } & "Fulfillment of Students' & & & \\
\hline & Expectation" & 3.702 & .876 & 4.00 \\
\hline & "Students' Satisfaction" & 3.867 & .581 & 4.00 \\
\hline & "Service Quality" & 3.859 & .594 & 4.00 \\
\hline & "Retention with HEOs" & 3.964 & .521 & 4.00 \\
\hline & “Overall HEOs & & & \\
\hline & Performance” & 3.898 & .561 & 4.00 \\
\hline \multicolumn{5}{|c|}{ "Overall HEOs performance level $\mathrm{M}=3.870, \mathrm{SD}=.440$, Median=4" } \\
\hline \multirow{5}{*}{$\begin{array}{l}\text { Leadership } \\
\text { Commitment }\end{array}$} & "Affective Commitment" & 4.645 & .269 & 4.669 \\
\hline & “Continuance & 4.574 & .329 & 4.500 \\
\hline & Commitment" & & & \\
\hline & "Normative Commitment" & 4.634 & .301 & 4.800 \\
\hline & "Overall LC level $\mathrm{M}=3.9$ & $=.334,1$ & & \\
\hline
\end{tabular}


Table 2 shows "the mean values against each factor of all the three scales it can be interpreted that in the sampled universities the HEOs are performing well. Leadership commitment scale shows even higher level however the continuance commitment is slightly more in practice than the other two dimensions of leadership commitment. Mean values of the table indicates that the participants showed more positive perceptions about the HEOs performance level and Leadership Commitment". Results show they are satisfied with the services of their respective institutions and also have positive opinion about leadership commitment in relation with institutional overall performance. Further, "a product moment correlation coefficient is conducted to find the nature and strength of the relationship between three variables. Before conducting the test the normality assumptions are checked in order to ensure the reliability of the test results. Kolmogrove-Smirnove statistics and QQ plots are used to check the normality of the data. According to the Kolmogrove-Smirnove statistics, if the value is above .05 then the data meets the normality assumption tests, a necessary assumption to be met for quantitative inferential or parametric tests such as correlations and regressions (Pallant, 2010). The Kolmogove-Smirnove statistics show that the values for score of leadership commitment and HEOs performance fulfilled the criteria of normality assumption as $\mathrm{P}=.423$ and .066 respectively the significance value is above .05 ".

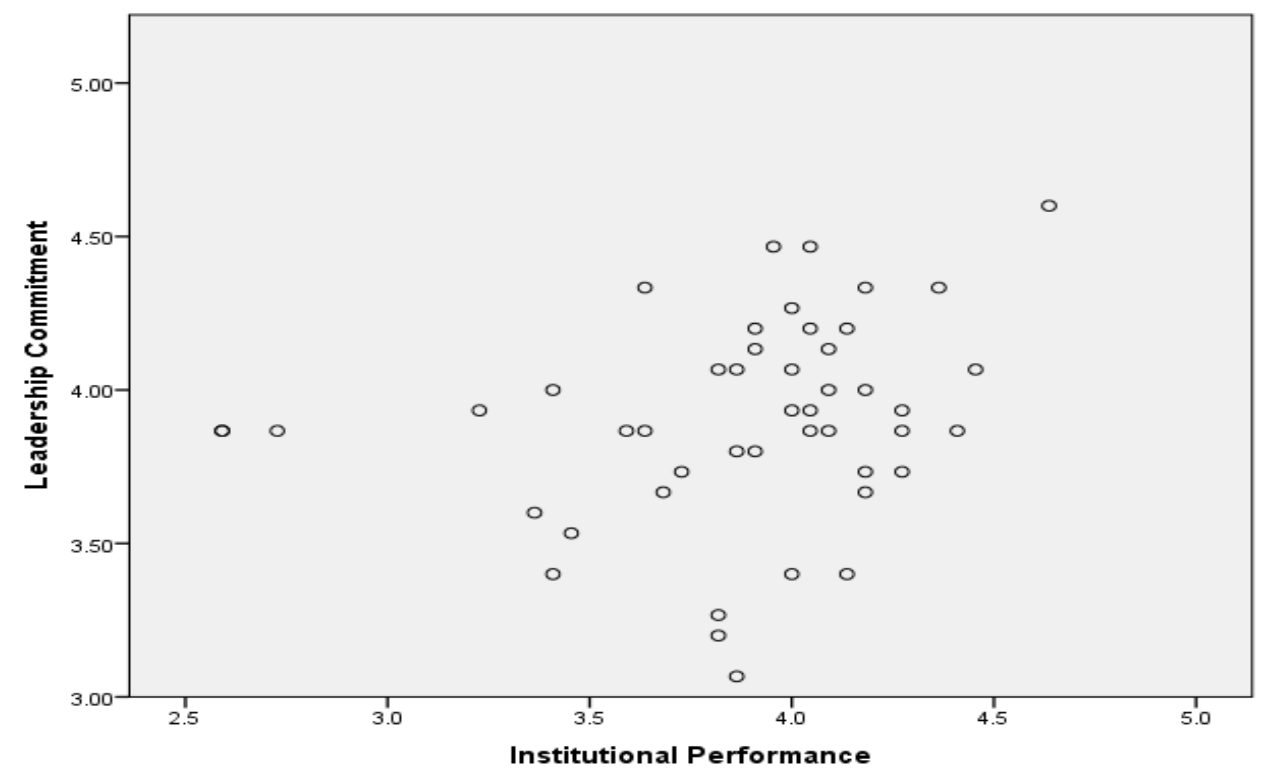

Figure 1: "Scatter Plot Showing the Direction of Relationship between LC and HEOs (Higher Education Organizations)"

In Figure 1 scatter plat shows "the direction of relationshipbetween leadership commitment and performance of highereducationorganizations. This figure indicates positive linearrelationshipbetweenboth variables". Table 3 presentsrelationship matrix between LC and HEOs performance factors.

Table 3 shows “relationship $(\mathrm{r}=.305)$ between LC and factors of HEOs' performance and it indicates that there is positive linear relationship between both variables. It also indicates that not only LC shows weak correlation with the factors of HEOs' performance but also the three types of leadership commitment indicated insignificant correlation. Since LC scale has three different types of commitment which may have variations and thus was expected to have a different results, nevertheless, overall it indicates a positive significant correlation with the performance factors of HEOs $(r=.305, \mathrm{p}<.05)$. The major conclusion of the study drawn from the relationship matrix which indicates there is linear positive relationship between leadership commitment and performance of higher education organization. However, these findings are carefully being generalized as sample size of the leaders was small in number". 


\begin{tabular}{|c|c|c|c|c|c|c|c|c|c|c|c|}
\hline \multicolumn{12}{|c|}{ "Relationship Matrix between LC and HEOs Performance Factors" } \\
\hline & Variables & 1 & $\begin{array}{l}2 \\
.484 *\end{array}$ & $\begin{array}{l}3 \\
.770\end{array}$ & $\begin{array}{l}4 \\
.639 *\end{array}$ & $\begin{array}{l}5 \\
.248\end{array}$ & $\begin{array}{l}6 \\
.158\end{array}$ & $\begin{array}{l}7 \\
.076\end{array}$ & $\begin{array}{l}8 \\
.231\end{array}$ & $\begin{array}{l}9 \\
.099\end{array}$ & $\begin{array}{l}10 \\
.639 *\end{array}$ \\
\hline 1 & “**LC" & - & - & $.223 *$ & -.186 & .064 & -.071 & -.175 & .203 & .022 & .212 \\
\hline 2 & $\begin{array}{l}\text { "AC" } \\
\text { "CC" }\end{array}$ & - & - & - & .268 & .264 & .148 & $.046^{*}$ & .303 & . 151 & .268 \\
\hline 4 & "NC" & - & - & - & - & .152 & .193 & .232 & -.032 & .021 & .115 \\
\hline 5 & “HEOs" & - & - & - & - & - & $.644^{*}$ & $.591 *$ & $.663^{*}$ & $.648^{*}$ & $.543 *$ \\
\hline 6 & "FSE" & - & - & - & - & - & - & $.648^{*}$ & $.468 *$ & $.372 *$ & $.508^{*}$ \\
\hline 7 & “SS" & - & - & - & - & - & - & - & $.591 *$ & $.663^{*}$ & $.553 *$ \\
\hline 8 & “SQ” & - & - & - & - & - & - & - & - & $.551 *$ & $661^{*}$ \\
\hline 9 & $\begin{array}{c}\text { "RI" } \\
\text { "OOP" }\end{array}$ & - & $\begin{array}{l}- \\
-\end{array}$ & $\begin{array}{l}- \\
-\end{array}$ & - & $\begin{array}{l}- \\
-\end{array}$ & $\begin{array}{l}- \\
-\end{array}$ & $\begin{array}{l}- \\
-\end{array}$ & $\begin{array}{l}- \\
-\end{array}$ & $\begin{array}{l}.231 \\
-\end{array}$ & $\begin{array}{l}.303 \\
.658^{*}\end{array}$ \\
\hline
\end{tabular}

"Note.*significance of relationshipat .05 "

"** LC=leadership commitment, withthreefactors of affective (AF), continuance (CC) and normative commitment (NC); HEOs =organizational performance with five factors of fulfillment of students' expectation (FSE), Students' satisfaction (SS), Service Quality (service quality), RetentionwithOrganization (RO), OverallOrganizational Performance (OOP)".

\section{Discussion}

Findings of the study show positive relationship between leasers' commitment and performance of higher education organizations. All the sub factors of leaders' commitment; affective, normative and continuous indicate linear positive relationship with institutional performance. These findings are consistent with previous studies which shows positive association of leaders' commitment and involvement with the performance and goals achievements of the organizations. Ibrahim and Daniel (2019) mentioned in their study that leaders set goals and directions for their employees and organizations' progress mainly depends upon leaders' dedication and devotion to work. Rachin (2001) stated in his study that leaders' are prime source of motivation in organization and play a vital role in the organizational progress. Furthermore, Messick and Kramer (2004) shed light on the crucial role of leaders' in up lifting the existing standard of the organizations and they reported in their study that leaders' role cannot be denied in the organizational progress and development. They also discussed that adverse consequences are being faced by organizations in case of leaders' negligence. Judge and Piccolo (2004) and Keller (2006) reported in their study that leadership is closely linked with organizational effectiveness and employees' performance. Various studies in the literature contains the concept of leadership commitment and organizational performance which endorses the positive relationship between these variables. It emphases that leaders are driving force behind organizational excellence and advancement. Moreover, current study also revealed that continuance leadership commitment is higher and shows mild positive correlation with performance. Continuous commitment relate to the needs of employees for which they stayed with the organization. Another reason linked to continuous commitment is when individuals do not have any other alternate work option so, they continue their work for the fulfilment of their needs (Werf, 2020). Such kind of variations of results are reported in the studies which leads to different conclusions. House and Aditya (1997) reviewed the existing literature regarding leadership involvement and performance and they explained that there is rich literature 
on these concepts but they highlighted the methodological issues and limitations of these studies which effect their findings and results. Therefore, in the current study leadership ratio is small in magnitude due which results are carefully being generalized. Overall literature is consistent with the findings that leadership's role play significant role in organizational performance (Schriesheim, Castro, Zhou \&Dechurch, 2006).

\section{Conclusion}

The study's findings lead to the conclusion that leadership commitment has positive relationship with organizational performance. Organizational excellence mainly depends upon the leaders' devotion and involvement within the organization. There are three different sub-factors of leadership commitment and the study shows all of these sub-factors have positive association with organizational performance. However, most of the respondents' shows that the level of continues commitment is higher which indicate that they are associated with the organizations for the sake of their own needs and this findings is based on practical situation. Overall, the findings of the study showed a positive association between leadership commitment and organizational performance.

\section{References}

Alexander, F. K. (2000). The changing face of accountability: Monitoring and assessing institutional performance in higher education. The journal of higher education, 71(4), 411-431.

Armstrong, M., \& Baron, A. (2000).Performance management. Human resource management, 69.

Choudhary, A. I., Akhtar, S. A., \&Zaheer, A. (2013). Impact of transformational and servant leadership on organizational performance: A comparative analysis. Journal of business ethics, 116(2), 433-440.

Dirks, K. T., \&Skarlicki, D. P. (2004). Trust in leaders: Existing research and emerging issues. Trust and distrust in organizations: Dilemmas and approaches, 7, 21-40.

Dubey, R., Gunasekaran, A., Childe, S. J., Papadopoulos, T., Hazen, B. T., \&Roubaud, D. (2018).Examining top management commitment to TQM diffusion using institutional and upper echelon theories. International Journal of Production Research, 56(8), 2988-3006.

Elenkov, D. S. (2002).Effects of leadership on organizational performance in Russian companies. Journal of Business Research, 55(6), 467-480.

Gerth, H. H., \& Mills, C. W. (1964). Character and social structure: The psychology of social institutions. Harvest/HBJ Book.

Ibrahim, A. U., \& Daniel, C. O. (2019).Impact of leadership on organizational performance.Journal of Business, Management and Social Research, 6(2), 367-374.

Jackson, T. A., Meyer, J. P., \& Wang, X. H. (2013). Leadership, commitment, and culture: A metaanalysis. Journal of Leadership \& Organizational Studies, 20(1), 84-106.

Judge, T.A., \& Piccolo, R.F. (2004). Transformational \& transactional leadership: A meta-analytic test of their relative validity. Journal of Applied Psychology, 89(5), 755-768.

Kakavogianni, D. (2009). Charismatic Leadership and its emergence under crisis conditions: A case study from the airline industry.

Kapur, R. (2019). Leadership Role in Educational Institutions. https://www.researchgate.net/publication/336639860_Leadership_Role_in_Educational_Institutions

Keller, R.T. (2006). Transformational leadership, initiating structure \& substitutes for leadership: A longitudinal study of research \& development project team performance. Journal of Applied Psychology, 91(1), 202-210.

Liou, Y. M., Jwo, C. J., Yao, K. G., Chiang, L. C., \& Huang, L. H. (2008). Selection of appropriate Chinese terms to represent intensity and types of physical activity terms for use in the Taiwan version of IPAQ. Journal of Nursing Research, 16(4), 252-263.

Malik, M. Y., Hussain, A., \&Nadeem, S. (2011). Flow of a Jeffery-six constant fluid between coaxial cylinders with heat transfer analysis. Communications in Theoretical Physics, 56(2), 345.

Messick, D. M., \& Kramer, R. M. (2004).The psychology of leadership, New Perspectives and 
Research.London: Longman Publishing Co.

Meyer, J. P., \&Herscovitch, L. (2001). Commitment in the workplace: Toward a general model. Human resource management review, 11(3), 299-326.

Mohsin, M. \& Kamal, M. A. (2012) Managing Quality Higher Education in Bangladesh: Lessons from the Singaporean and Malaysian Strategies and Reforms. International Journal of Business and Management, 7(20): 59-70.

Mueller, G. H. (1979). The notion of rationality in the work of Max Weber. European Journal of Sociology/Archives Européennes de Sociologie/EuropäischesArchivfürSoziologie, 20(1), 149-171.

Mumford, T. V., Campion, M. A., \&Morgeson, F. P. (2007). The leadership skills strataplex: Leadership skill requirements across organizational levels. The Leadership Quarterly, 18(2), 154-166.

Nasomboon, B. (2014). The relationship among leadership commitment, organizational performance, and employee engagement. International Business Research, 7(9), 77-89.

Okahara, K., Ishida, Y., Hayashi, Y., Inoue, T., Tsuruta, K., Takeuchi, K., \& Yoshida, K. (2010).Effects of Yokukansan on behavioral and psychological symptoms of dementia in regular treatment for Alzheimer's disease. Progress in Neuro-Psychopharmacology and Biological Psychiatry, 34(3), 532536.

Pounder, J. (1999). Institutional performance in higher education: is quality a relevant concept?. Quality Assurance in Education.

Rachin (2001).Impact of leadership on organization. New Jersey: Prentice Hall Inc.

Schriesheim, C.A., Castro, S.L., Zhou, X., \&Dechurch, L.A. (2006).An investigation of path-goal \& transformational leadership theory predications at the individual level of analysis.The Leadership Quarterly, 17(1), 21-38.

Shin, J. C. (2010).Impacts of performance-based accountability on institutional performance in the US. Higher Education, 60(1), 47-68.

Sopian, K., \&Daud, W. R. W. (2006). Challenges and future developments in proton exchange membrane fuel cells. Renewable energy, 31(5), 719-727.

Spiegelhalter, D. J. (2005). Funnel plots for comparing institutional performance. Statistics in medicine, 24(8), 1185-1202.

Ulewicz, R. (2017). The role of stakeholders in quality assurance in higher education. Human Resources Management \& Ergonomics, 11(1).

Weeks, C., Kim, R., Wolgamod, M., Whelan, G., \& Faisal, M. (2011). Experimental infection studies demonstrate the high susceptibility of the salmonid, lake herring, Coregonusartedi (Le Sueur), to the Great Lakes strain of viral haemorrhagicsepticaemia virus (genotype IVb). Journal of fish diseases, 34(11), 887-891.

Werf, R. (2020). Three Key Types of Organizational Commitment.Retrieved from https://www.effectory.com/knowledge/3-key-types-of-organisationalcommittment/\#: :text=assets\%20for\%20organisations.,Continuance\%20commitment,to\%20stay\%20with\%20the\%20organisation.

Whitener, E. M., Brodt, S. E., Korsgaard, M. A., \& Werner, J. M. (1998). Managers as initiators of trust: An exchange relationship framework for understanding managerial trustworthy behavior. Academy of management review, 23(3), 513-530.

Wright, T. A. (1997). Job performance and organizational commitment. Perceptual and Motor Skills, 85(2), 447-450.

Yammarino, F. J., Dionne, S. D., Chun, J. U., \&Dansereau, F. (2005). Leadership and levels of analysis: A state-of-the-science review. The leadership quarterly, 16(6), 879-919. 